
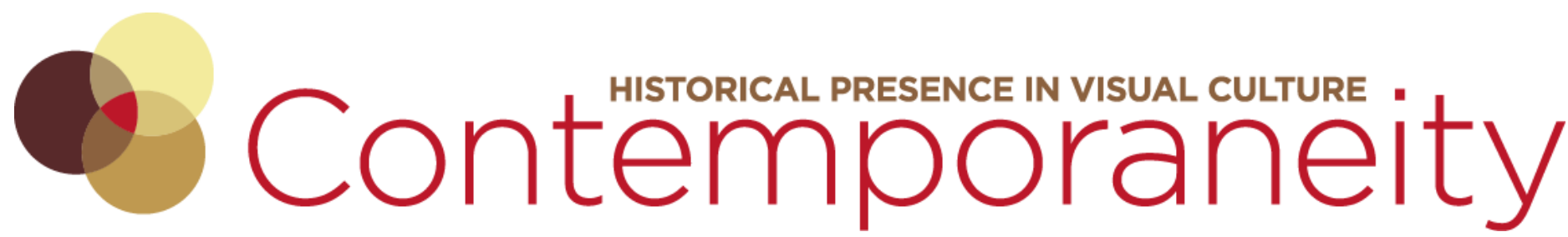

Vol 6, No 1 "Boundless" (2017) | ISSN 2153-5914 (online) | DOI 10.5195/contemp.2017.206

http://contemporaneity.pitt.edu

\title{
Historical Contemporaneity and Contemporaneous Historicity Creation of Meaning and Identity in Postwar Trauma \\ Narratives
}

Thorsten Wilhelm

\begin{abstract}
This paper contends that traumatic memories are not inherently memories of an experienced trauma. It explores a new perspective on post-1945 Jewish-American fiction. Analyzing Jewish-American novels from three generations-survivors, their children, and their grandchildren-the author traces the trajectories and changing perspectives in the narrative productions of these three generations. The analysis uses Jeffrey Alexander's theory of cultural trauma to analyze generational trajectories in identity formations.
\end{abstract}

\section{About the Author}

Thorsten Wilhelm is a doctoral student in the English Department at Heidelberg University and an Exchange Scholar at Yale University. He received his MA in History and English Literature and Linguistics from Heidelberg University. His research focuses on the ongoing effects of the Holocaust in Jewish-American fiction. He looks at how these intergenerational trauma narratives form identities and collective trauma. Apart from this, his interest in nineteenth-century literature has him working on bibliographical histories of engravings for the novels of Charles Dickens. 


\section{Generational Trauma}

\section{Historical Contemporaneity and Contemporaneous Historicity Creation of Meaning and Identity in Postwar Trauma Narratives}

Like other narratives, trauma narratives follow a process of "coding, weighting, and narrating,"1 constituting a $\mathrm{co}(\mathrm{n})$ temporaneous past that exceeds the bare facts. The past becomes not just contemporaneous, but cotemporaneous in its experiential quality. For that, it is necessary to distinguish between stories that retell an individual trauma and cultural narratives that evolve from the continuous generational engagement with such

traumas. Humans tell stories to interlink their identities with others and establish a contemporaneity: a contemporaneity that allows storytellers to approach as closely as possible a reality they may or may not have experienced themselves. ${ }^{2}$ In this quest, the past is a vital source of-and a powerful force in-defining the present(s) and the future(s). ${ }^{3}$ Contemporaneity is distinct for each generation: every generation, every individual seeks to create a unique version, which is invariably filled with their own pertinent questions for both present and future. One "generation feels keenly what another barely notices," one "appreciates (or dreads)" what "another takes for granted." ${ }^{4}$ It is this drive for an understanding and need to experience something of an other's past trauma that fuels the trauma narratives of those who have not lived through the Holocaust.

\section{Commemorative Narratives}

Related to this urge to re-present memory, history, and trauma is the attempt, in narrative, to build a whole self with a stable, independent identity. It is an attempt grounded temporally for both individual and collectivity. To achieve this goal, accounts of the (traumatic) past, present perceptions, and dreams and hopes for the future need to unify into a coherent narrative, making trauma narratives both a disruptive and a unifying factor for identity formation, which is why Ron Eyerman sees the role of memory in identity formation as the narrativized account of one's past-the "part of the development of the self or personality." ${ }^{5}$ Memory, thus, is the key anchor in the tides of time, allowing us to

1 Jeffrey C. Alexander, "The Social Construction of Moral Universals," in Remembering the Holocaust. A Debate, ed. Jeffrey C. Alexander (Oxford: Oxford University Press, 2009), 7.

2 Eugene Hollahan, "Saul Bellow: Vision and Revision by Daniel Fuchs; Saul Bellow and History by Judie Newman," Studies in the Novel 20 (1988): 104.

3 Rachel M. Herweg, Die jüdische Mutter: Das verborgene Matriarchat (Darmstadt: Wissenschaftliche Buchgesellschaft, 1994), 6.

${ }^{4}$ Hana Wirth-Nesher and Michael P. Kramer, "Introduction: Jewish American Literatures in the Making," in The Cambridge Companion to Jewish American Literature, ed. Hana Wirth-Nesher and Michael P. Kramer (Cambridge: Cambridge University Press, 2003), 5.

5 Ron Eyerman, "Slavery and the Foundation of African American Identity," in Cultural Trauma and Collective Identity, ed. Jeffrey C. Alexander et al. (Berkeley: Polity Press 2004), 64-65. 
construct our individual and collective selves. ${ }^{6}$ Remembering the past, then, is-as Proust describes in In Search of Lost Time-not an actualization of the past. In remembering, we do not recreate a Rankean past "as it actually was" but as we perceive it at the present moment: it is re-presented. ${ }^{7}$ In remembering, one constructs a revivified narrative of a past in which the memory is formed by a present subjectivity. ${ }^{8}$

This kind of remembrance, for those who have not experienced the Holocaust, is fraught with complications. Gary Weissman stresses the desire of children of Holocaust survivors "to become a prisoner, to actually feel the horror - in short, to witness the Holocaust as if one were there." to those who are the children of Holocaust survivors," but pertains to "many people who have no direct experience of the Holocaust but are deeply interested in studying, remembering, and memorializing it." ${ }^{10}$ As such, discrepancies among factual reality, survivor memory, and non-survivor imagination become complicated. "Finally, it was hearing stories [...] at the very scene of the crime," which allows those without a Holocaust experience "to come closest to something of the missing horror, however fleetingly." 11 The closeness to and of the narrative is the means of connecting to a place and a time that otherwise could not be made $\operatorname{co}(n)$ temporary. Hearing the stories transforms hitherto historically significant places into those that are personally informed.

Conceptually, only the survivors have a direct link to some aspects of the Holocaust. Their individual trauma is specific to their experiences and gives rise to individual stories and memories which, in and of themselves, create access points for the post-Holocaust generations who want to connect to the trauma of their ancestors. To achieve this connection, "the tendency to privilege and identify with those histories that resonate with one's own sense of identity" is the vital touchstone to make the past trauma a contemporaneous identity. ${ }^{12}$ The generations of children and grandchildren of Holocaust survivors implement their forebears' memories into their own memories and identities. ${ }^{13}$ By imagining the narratives they hear, or do not hear, they form memories of a possible story which are realized as actual memories of events they did not, in reality, live through. Nevertheless, the experiential quality is quite similar. Hearing their parents' stories and

6 Jeffrey K. Olick, "Introduction," in The Collective Memory Reader, ed. Jeffrey K. Olick, Vered Vinitzky-Seroussi, and Daniel Levy (New York: Oxford University Press, 2011), 37.

7 Christoph Münz, "Alles Was Ich Tun Kann Ist diese Geschichte zu Erzählen: Erinnerung und Gedächtnis im Judentum und Christentum," in Die Gegenwart des Holocaust: "Erinnerung" als Religionspädagogische Herausforderung, ed. Michael Wermke (Münster: Lit, 1997), 73.

8 Alan Megill, "History, Memory, Identity." In The Collective Memory Reader, ed. Jeffrey K. Olick, Vered Vinitzky-Seroussi, and Daniel Levy (New York: Oxford University Press, 2011), 196.

9 Gary Weissman, Fantasies of Witnessing: Postwar Efforts to Experience the Holocaust (Ithaca/London: Cornell University Press 2004), 4.

10 Weissman, Fantasies, 4. We remember also Lawrence Langer's now-famous statement about the high standards and dangers of engaging scholarly with the Holocaust.

11 Weissman, Fantasies, 5.

12 Weissman, Fantasies, 7.

13 In the following, I use the term first generation for the generation of Holocaust survivors. The second generation are the children of the survivors. The third generation denotes the grandchildren of survivors. Although these distinctions are sometimes identical with literary or cultural generations, that is not always the case. 
imagining them-that means actualizing these narratives-in the present re-members ${ }^{14}$ them within their pertaining contemporary identity. Memory, here, is not a remembrance of isolated incidents, but the construction of a meaningful narrative which allows for an inscription into others' contemporaneous identities: the formation of a usable past, a livable present, and a wishable future. ${ }^{15}$

\section{Processing Trauma}

In this endeavor, writers become makers of meaning and architects of reality because their subject matter is the whole temporal continuum of which man tries to make sense by binding together past, present, and future. ${ }^{16}$ Where does fact end and fiction begin? How factitious is fiction? How fictitious is fact? I inquire into the narrative collectivization of a historical event over three generations of literary engagement to analyze how, to borrow Jeffrey Alexander's phrase, "a specific and situated historical event, an event marked by ethnic and racial hatred, violence, and war, becomes transformed into a generalized symbol of human suffering and moral evil."17

I will follow the theory of cultural trauma developed by Alexander, who sketches the history of the perception of the Shoah from Nazism-related war "atrocities" via a progressive narrative to a tragic narrative that went hand in hand with inaugurating the Holocaust's status as unique and universal. ${ }^{18}$ This development is essential in understanding the emergence of the Holocaust as an event of cultural trauma that is very much alive for later generations whose predecessors, although being closer to it, felt no or little connection to. ${ }^{19}$ This phenomenon is in addition and contrast to what Marianne Hirsch called "postmemory," 20 a form of nonmemory or absent memory of the later generations that spawned a varied and

14 Remembering here takes on two meanings: first, to bring them back to mind and hand them down from generation to generation and, second, to inscribe themselves, through this memorial act, as members of the collectivity of the traumatized.

15 Paul Connerton, How Societies Remember (Cambridge/New York: Cambridge University Press, 1989), 26

16 See, in this context, the Heraclitian sentiment that "[e]verything changes and nothing remains still. You cannot step twice into the same stream" (Rapp 2007, 67). According to Heraclitian philosophy, history is a constant temporal stream, which is never the same at two different points of time. See also, the Augustinian doctrine that "if the present time were always present and weren't blending into the past, it wouldn't be time anymore but eternity" (Meijering, 1979, 59). Time is seen as a whole that cannot be put into human histo-temporal categories, but is instead an auxiliary construction to grasp reality (Harpham 1985, 81; Stein 1984, 7). It follows, that "beliefs in a historical past from which men might learn any simple, substantial truth" are false, as "there were as many 'truths' about the past as there were individual perspectives on it" (White 1973, 332). For Nietzsche (2010, 42), "[t] he unrestrained historical sense, pushed to its logical extreme, uproots the future, because it destroys illusions and robs existing things of the only atmosphere in which they can live" (Grass 1983, 128-29; Anchor 1987, 121-22).

17 Alexander, "Social Construction," 3.

18 Alexander, "Social Construction," 3-32.

19 Alexander, "Social Construction," 3.

20 Marianne Hirsch, The Generation of Postmemory: Writing and Visual Culture after the Holocaust (New York: Columbia University Press, 2012). 
complex literary output in the attempt to approach the trauma. ${ }^{21}$ This "postmemory" deserves further analysis vis-à-vis Alexander's theory.

Whereas Alexander "explores the social creation of a cultural fact and the effects of this cultural fact on social and moral life, ${ }^{\prime 22}$ I explore the literary narratives produced both as cause and effect of this social construction and its metamorphoses over the generations. The "canon"23 of Jewish American fiction establishes dialogues between individuals and groups and, thus, allows for interrelated and/or opposing representations of identity. As part of the literary tradition, the narratives form horizons on which we see how individuals and collectivities inscribe their identities as created by inclusion and exclusion of aspects of the collective identity.

Individually, those who lived through the Holocaust are traumatized by the atrocities they experienced. Collectively, this trauma was transmitted to the following generations who are traumatized by its aftermath. The survivors' tales foster a tradition of Holocaust narratives that perpetuates the trauma, transmitting it to the following generations-thereby engaging in a certain healing process. But these tales also constitute a connective collective experience $^{24}$ through the need of later generations to incorporate the traumatic contemporaneity into their own contemporaneity, that is the identities they narrate both of and for themselves. First-generation testimonies, especially Elie Wiesel's Night, use narrative stylistic features to draw the reader into, and stir engagement with, the trauma stories by simultaneously propagating the incomprehensibility and incommunicability of the Holocaust.

These individual renditions establish a collective narrative of the trauma that traumatizes even later generations. This can be seen, Alexander argues, "when members of a collectivity feel they have been subjected to a horrendous event that leaves indelible marks upon their group consciousness, making their memories forever and changing their future identity in fundamental and irrevocable ways. ${ }^{25} \mathrm{He}$ asserts that a cultural trauma is not a priori in the world, that is events, on the cultural level, are not inherently traumatic. ${ }^{26}$ Rather, what creates a cultural trauma are the individual and collective attributions to an event. 27

21 Ellen S. Fine, "Intergenerational Memories: Hidden Children and Second Generation," in Remembering for the Future: The Holocaust in an Age of Genocide, vol. 3, Memory, ed. John K. Roth and Elizabeth Maxwell (Basingstoke: MacMillan, 2010), 187.

22 Alexander, "Social Construction," 3.

23 I will not attempt to define a comprehensive and exhaustive canon of Jewish American fiction-let alone literature. This effort has been undertaken and is currently being worked on by eminent scholars such as Ruth R. Wisse and Justin Cammy, to name but two. Following Jan Assmann, I will merely use my individual "canon" as a principle of the interrelation of collective and individual identity formation through and in works of fiction. I hold that the works I analyze describe, form, change, and discard the normative consciousness of a whole population and the individuals who relate their identities to it (Cammy 2008; Wisse 2000).

24 See Joseph Soloveitchik's "covenant of fate" in denoting such a formation of a collective identity along the narratives about the Holocaust trauma (Kaplan 2005, 5).

25 Jeffrey C. Alexander, "Toward a Theory of Cultural Trauma," in Cultural Trauma and Collective Identity. ed. Jeffrey C. Alexander et al. (Berkeley: University of California Press, 2004), 1.

\footnotetext{
26 Jeffrey C. Alexander, Trauma. A Social Theory (Cambridge, MA: Polity. 2012), 13.

27 Alexander, "Toward a Theory," 8.
} 
But trauma leaves ruptures "in the web of meaning," thereby constricting the construction of "meaningful histories." 28 That is why fictional traumas are sometimes no less traumatizing than factual ones. Trauma "becomes a thing by virtue of the context in which it is implanted." ${ }^{29}$ As such, trauma generates traumatic narratives that must be remembered in order to be worked through and spoken out. ${ }^{30}$ Individual and collective traumatic memories continue through narratives, which, again, change over time as new memories are found or formed in the construction of coherent narratives by victims and following generations. Accordingly, the original trauma, while being worked through, is re-enacted by subsequent generations.

Generationally, our present and past involvements are causally connected. On one hand, our perception of the past depends on present influences. On the other, the past influences our perception of the present. ${ }^{31}$ Trauma narratives, hence, play an important role in studying post-Holocaust Jewish-American fiction, as highlighted by Yael Zerubavel, who contends that

[e]ach act of commemoration produces a commemorative narrative, a story

about a particular past that accounts for this ritualized remembrance and

provides a moral message for the group members. [...] collective memory

clearly draws on historical sources. Yet it does so selectively and creatively. [...]

the commemorative narrative [...] undergoes the process of narrativization. ${ }^{32}$

Post-1945 Jewish-American fiction, in many respects, constitutes such "commemorative narratives." In Alexander's theory, trauma simultaneously constitutes a disruptive and a constructive force in identity formation. ${ }^{33}$ Remembering becomes an act of putting memories into meaningful narrative sequences that invest one's present with meaning, irrespective of whether the remembered entities are based on fact.

There cannot, of course, be a single adequate and accurate memory; rather, there is a multiplicity of memories. ${ }^{34}$ This highlights the basic principle: while "survivors persist in writing memoirs to bear witness to their encounter with death. [...] Children of survivors are trying to come to terms with the wounds they have inherited. ${ }^{\prime 35}$ In this process, imaginative narratives are paramount because they create meaningful stories that allow for coherence and grounding by filling gaps either fictionally or by incorporating other people's memories. Necessarily, this process, to a lesser extent, pertains also to survivor testimonies, since no

28 Bernhard Giesen, "The Trauma of Perpetrators: The Holocaust as the Traumatic Reference of German National Identity," in Cultural Trauma and Collective Identity. ed. Jeffrey C. Alexander et al. (Berkley: University of California Press, 2004), 113.

29 Neil J. Smelser, "Psychological Trauma and Cultural Trauma," in Cultural Trauma and Collective Identity, ed. Jeffrey C. Alexander et al. (Berkeley: University of California Press, 2004), 34.

30 Giesen, "Trauma of Perpetrators," 113.

31 Connerton, How Societies, 2.

32 Yael Zerubavel, Recovered Roots: Collective Memory and the Making of Israeli National Tradition (Chicago: The University of Chicago Press, 1995), 237.

33 Cf. the Holocaust trauma and second-generation identification, not with the following generations' own present reality but with their parents' memories. It shows the need to incorporate the traumatic memories, which constitute a connective collective experience to interlink one's identity with others.

\footnotetext{
34 Fine, "Intergenerational Memories," 78.

35 Fine, "Intergenerational Memories," 78.
} 
survivor can represent the Holocaust or even one concentration camp experience in its entirety, ${ }^{36}$ which is why works engaging with the tradition of Holocaust testimonies can be seen as "works born of belated trauma." ${ }^{137}$

There is not one Holocaust trauma, but a range of traumata born from the specifity of one's experiences at a certain time and location within the event. Each trauma is specific to the context in which it occurs. Taken together as an evolved and evolving collective narrative, the respective experiences and traumata form a story of a collective trauma. At the same time, the Holocaust trauma constitutes several collective identities that must be differentiated: the identity of survivors, of the second and third generations, and of all those living in the aftermath of the Holocaust. ${ }^{38}$ Each identity is marked by specific scripts, which the individual has and which she follows to ground herself. To analyze the use, function, and implications of these scripts, one must analyze the intergenerational "contingent, sociologically freighted nature of the trauma process[es]." 39 Such an intergenerational approach to the literary productions is significant because the effects of the cultural trauma have not yet been studied in depth. An analysis based on Alexander's theory shows that a good many studies of Jewish-American fiction

\begin{abstract}
fail to see that there is an interpretive grid through which all "facts" about [the Holocaust] trauma are mediated ... [It] has a supraindividual, cultural status; it is symbolically structured and sociologically determined. No trauma interprets itself. Before trauma can be experienced at the collective (not individual) level, there are essential questions that must be answered, and answers to these questions [and the questions themselves] change over time. ${ }^{40}$
\end{abstract}

These changes are overtly and covertly reflected in the literary outputs of each generation. When we are interpreting the world and our perceptions of it, we do so by constructing texts that reflect our rootedness in our respective contemporaneities-social, historical, communal, regional, geographical, religious, temporal, and so forth.

We should not forget that, although the Holocaust traumatized each survivor, spawning a plethora of narrative and creative engagements, Jewish-American fiction is more than a mere literature of the Holocaust. Third-generation works such as All Other Nights, in which Dara Horn explores another kind of Jewish trauma experience during the American Civil War of 1861-1865, and What We Talk About When We Talk About Anne Frank, in which Nathan Englander explores a wider range of questions about Jewish identity in a post-

36 Weissman, Fantasies, 1-5.

37 This is a form of individual, i.e., "psychological," trauma and not one of cultural trauma as Alexander conceptualizes it. These two concepts, while compared, should not be intermixed or blurred.

38 Marita Grimwood, in her study Holocaust Literature of the Second Generation (New York: Palgrave Macmillan, 2007) underlines the inherent transnationality of second-generation literature-a fact easily expandable to both first- and third-generation writing as well. According to Grimwood, "[s]econdgeneration writing is by its nature an international field. While not wishing to elide the cultural specificities of immigrant experiences and memorial traditions, it is clear that in this case drawing rigid boundaries between national literatures is both arbitrary and limiting. Owing to the nature of postwar migration, even pinning a given writer down to a single country can be difficult" (2). In the following, however, we contend that analyzing works written from within a specific cultural context-the United States-nevertheless accounts for certain features pertaining and originating specifically from this context.

\footnotetext{
39 Alexander, "Social Construction," 7.

40 Alexander, "Social Construction," 7.
} 
Holocaust world, producing particularly illuminating narratives in looking beyond the trauma by building upon it.

\section{First-Generation Testimony}

The 1970s saw the beginning of a tradition of sharing testimony of one's experiences during the Holocaust with a more widely interested audience. Before that, stories of the traumatic experiences were not welcomed by the larger public. Perceptions of the survivor also changed. ${ }^{41}$ Ellen S. Fine's statement that "the afterlife of the Holocaust [...] has expanded in the $1990 \mathrm{~s}^{\prime \prime}$ reflects this growth of testimonial material. ${ }^{42}$

Direct testimony fostered the emergence of survivors as a new concept in the trauma discourse because they provided a "tactile link with the tragic event. As their social and personal role was defined, they began to write books, give speeches to local and national communities, and record their memories of camp experiences on tape and video." 43 The trajectory of silence and testimony can be seen in the example of Elie Wiesel, who at first imposed a pledge of silence upon himself:

I knew that the role of the survivor was to testify. Only I did not know how. I lacked experience, I lacked a framework. I mistrusted the tools, the procedures. Should one say it all or hold it all back? Should one shout or whisper? [...] And then, how can one be sure that the words, once uttered, will not betray, distort the message they bear? [...] So heavy was my anguish that I made a vow: not to speak, not to touch upon the essential for at least ten years. Long enough to see clearly. Long enough to listen to the voices crying inside my own. Long enough to regain possession of my memory. Long enough to unite the languages of man with the silence of the dead. ${ }^{44}$

\footnotetext{
41 The survivors' testimonies emblematize the problems that arise on expressing and working through the traumatic events. Lived-through atrocities or witnessed atrocities together form the trauma that the survivors need to work through. Temporal, geographical, and, most importantly, linguistic distance is needed to be able to construct a meaningful narrative. Although clearly based on fact and actual events, each testimony is also a novel or, to use Claire Colebrook's $(1997,16)$ expression, a "discursive event." Hence, it incorporates historical facts into "a collection of new relations," filling up gaps and establishing links to foster coherence. The consecutive literary traditions, then, are clearly and unavoidably works of fiction. The factual element in second- and third-generation literary productions is based on "historical evidence" and the accounts of "those who were there." The fictional element is that they imaginatively connect to the factual events trying to grasp, or even experience, the trauma they have inherited as parts of their past. In connecting to their parents' trauma, the second generation faces elemental difficulties. For one, they do not have actual memories of the trauma they have inherited from their parents' stories and physical and psychological suffering. Also, their parents' actual memoriesemotional and bodily reactions-cannot be transformed into their own memories one to one. Nevertheless, their imaginative effort-as realized in their works-allows them to approximate their parents' memories in their "affective and psychic effect" that Marianne Hirsch $(2012,31)$ terms "postmemory." The concept of postmemory is based on the premise that, for the children, who actually had to cope, if not with the trauma itself, then with its aftereffects, the Holocaust is "a memory not of theoretical abstraction or ideological strategies, but of proximity charged with feeling" (Hoffman 2004, 180).

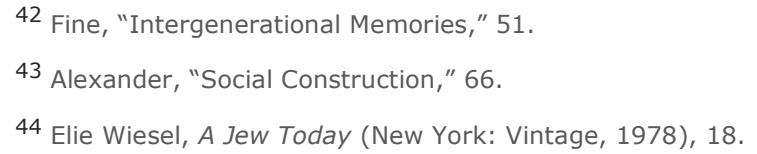


Wiesel's Night and the implications of his "vow" deserve reevaluation considering intergenerational trauma narratives, especially since Wiesel claims that his work is born from silence. "I entered literature through silence," Wiesel states in an interview,

I seek the role of witness, and I am duty bound to justify each moment of my life as a survivor. [...] Words can never express the inexpressible; language is finally inadequate, but we do know of the beauty of literature. We must give truth a name, force man to look. The fear that man will forget, that I will forget, that is my obsession. Literature is the presence of the absence. Since I live, I must be faithful to the memory. [...] I must be the emissary of the dead, even though the role is painful. If we study to forget, live to die, then why? The question is the answer; what I do, what I write, is the answer. I write to understand as much as to be understood. Literature is an act of conscience. It is up to us to rebuild with memories, with ruins, with efforts, and with moments of grace. ${ }^{45}$

Caruth thought-provokingly approaches the theoretical stance of the unknowability, incomprehensibility, inexplicability, and inexpressibility of the Holocaust and its ensuing traumata with an interest "in the complex relation between knowing and not knowing," because it is at this intersection "that the language of literature and the psychoanalytic theory of traumatic experience precisely meet."46 The nexus where knowing, not-knowing, and the emerging narratives to imbue meaning in the events through language meet is vital in this context. Contrary to Caruth's theorem of the incomprehensibility of the initial trauma experience, however, Richard McNally contends that the trauma is available to the victim initially and fully. In the cases where there is a silence, that silence is either voluntarily or involuntarily imposed on the victims as a result of personal needs or the public audiences' reaction to the trauma narratives. ${ }^{47}$ This is not a form of repression, since the memory of trauma remains virulent in the victim, but a form of not talking about it.

In the narrative quest for understanding and meaning creation (as highlighted in Alexander's theory of a coded, weighted, and narrated collective narrative in the face of destroyed meaning), the trauma narratives make the initial, individual experiences and memories of the trauma available to those who have not experienced it or who have experienced it differently. There, in the open space of public and literary discourse, is the "truth, in its delayed appearance and its belated address" merged with "what is known, but also [with] what remains unknown in our very actions and our language." 48 Moreover, the collective narrative starts to haunt those who have not experienced the horrors themselves but are drawn into the victims' traumatic narratives.

Wiesel published the Yiddish ...Un die velt hot geshvign with significant differences to the later Night. All English versions of Night are translations of the French version. Most importantly, Wiesel's work allows for an analysis of fictional versus historical truth and of how the narrativization of memory shapes the perception of the Holocaust. Apart from that,

45 Heidi Anne Walker/Elie Wiesel, "How and Why I Write: An Interview with Elie Wiesel," The Journal of Education 189, No. 3, REFLECTION and RENEWAL (2008/2009): 49-50.

46 Cathy Caruth, Unclaimed Experience: Trauma, Narrative, and History (Baltimore, MD: The Johns Hopkins University Press 1996), 3.

47 Richard J. McNally, Remembering Trauma (Cambridge, MA: The Belknap Press of Harvard University Press 2003).

48 Caruth, Unclaimed Experience, 4. 
Night lies in the middle of a significant transitional period in the social construction of the Holocaust. Not only is Wiesel's account located at a point in time when communal perception of the Holocaust began to change from a progressive to a tragic narrative, but also, he helped in making that transition.

Night, as a paradigmatic narrative, has had a strong impact on subsequent discourses about Holocaust trauma and how it has been narrativized. Wiesel artistically and poetically recounts the unspeakable events and uses historical and fictional reappraisal to bridge the void of silence and memory loss through testimony and narrative. Thereby Wiesel powerfully shows that the inexplicability and unspeakability is no hindrance to speak of it and to find linguistic expressions to approach the subject. As Naomi Seidman emphasizes, Wiesel's-and trauma discourses in general-stylization of the unsayable is not what cannot be expressed at all but "what cannot be spoken in French." 49 Wiesel's use of narratological techniques to tell his experiences, to relate to his experiences, and to mediate these experiences, as well as the way those techniques establish or reestablish a certain degree of identity after the trauma, help understand the literary productions of the following generations. These productions are, in themselves, new building blocks for new identities. Seidman, in her comparative analysis of Night and ...Un die Velt holds the different endings to be two "entirely different account[s] of the experience of the survivor." 50 She sees the ending of Night to be a projection of Eliezer, the surviving protagonist, into the post-Holocaust world in which the witness becomes a torn mediator between the need to speak and the silence and death born by an unspeakable event. Seidman conceptualizes this as a change in the witness's identity, arguing that ... Un die Velt portrays the enraged "Yiddish survivor [who] shatters that image as soon as he sees it, destroying the deathly existence the Nazis willed on him." This depiction would fit into the context of what Alexander calls the progressive narrative, an enraged but teleologically oriented outlook that underlines the need to shatter the trauma for life to go on. In Night, on the other hand, the narrative projects "liberated Eliezer's death-haunted face into the postwar years when Wiesel would become a familiar figure," and when the outlook had changed to a tragic narrative, which constituted the survivor as an eternally maimed figure who needs to be held in awe because of the message delivered by the witness of trauma. ${ }^{51}$

An interesting counterpoint is Louis Begley's 1991 novel Wartime Lies. Begley, who spent the war years hiding in Poland with his mother under a fake identity, will-although not a survivor of a concentration camp-be dealt with as a witness of the traumatic events of the Holocaust. Begley, in contrast to Wiesel, never claims that his account is mnemonically or historically accurate (he writes, after all, nearly fifty years after the events). On the contrary, he offers the possibility of fictional freedom and narrative contortion. Begley claims "the freedom to invent, consistent with the profound moral and psychological truth of the story." 52 He holds that "the passage of time and exile" functions as "a psychic screen" that helped him grapple with the topic. ${ }^{53}$ Like Wiesel, he needed temporal distance.

49 Naomi Seidman, "Elie Wiesel and the Scandal of Jewish Rage," Jewish Social Studies: New Series, 3 (1996): 8.

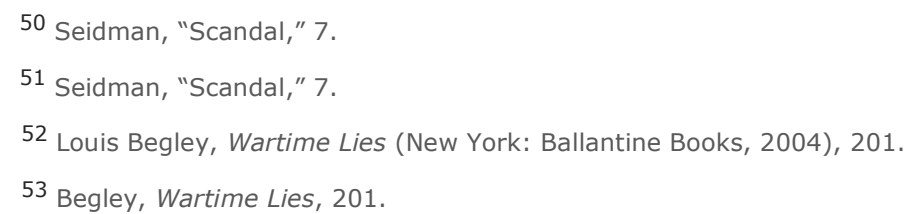


However, in contrast to Wiesel, who stresses mnemonic and historical accuracy, Begley emphasizes that Wartime Lies represents one possible memory and possible identity. This does not necessarily make his account a lie, but allows for a deeper understanding of the process of fictionalizations. Both Wiesel and Begley stress that temporal distance is crucial in understanding and narrating the experiences, but Begley writes that Wartime Lies is "quintessentially a work of fiction and not an autobiography or memoir, and that I had to write the story [...] in the form of a novel. The form was no less necessary than the emotional distance from the events I was going to evoke conferred by exile and the passage of time." 54

A valuable excursus here is the Holocaust hoax Fragments. Memories of a Childhood, 1939-1948 by Binjamin Wilkomirski alias Bruno Doesekker alias Bruno Grosjean, because it unfolds questions about the possibility of such strong identification with the Holocaust that one creates one's own account of it. ${ }^{55}$ To be more precise, Wilkomirski identifies so deeply with the ex post facto collective narratives as to make them his new, lived identity. Fragments provides an interesting counterpoint to the survivor testimonies and bridges the gap not only to authors like Saul Bellow, ${ }^{56}$ Philip Roth, ${ }^{57}$ and Cynthia Ozick, ${ }^{58}$ who are contemporaries of the Holocaust, although spatially and experientially removed from the events, but also to second- and third-generation writers. I do not intend to qualify one account as more genuine or less truthful than another. It is much more fruitful to analyze the implications that arise with this account and its reception-the need to identify with a traumatic event and a certain narrative about it, as well as the need to establish one's own account of a memory that one has without it being one's own memory. It is a striking example of how a collective trauma can be used to inscribe one's identity.

In a poetic narrative mode, the novels engage with the individual's universal problems of contemporaneity in a present infused with traumatic narratives. Tradition, community, and culture are paramount. In the historical nexus, the individuals need to inscribe themselves into their respective version of history by creating meaning from the past. A whole self and a livable present is possible only by bringing past, present, and future into co(n)temporaneity.

\section{Second Generation}

The second generation's literary output is marked by the conflict arising from the inherited parental trauma, which they feel as if it were their own but of which they have no personal memory. They must necessarily overcome past traumata: not only the Holocaust, but also forgetfulness, fragmentation, their personal fears, and unrealized hopes. Living in the present cannot be achieved if the individual is overwhelmed by the past. The protagonists in second-generation novels-mainly members of the second-generation themselves-yearn for a present wholeness of self and a stable identity. The parents' trauma poses a tremendous legacy that counteracts this yearning. Not only do the children bear witness to the trauma, but they also must "never forget!" so that later generations will know what happened and

\footnotetext{
54 Begley, Wartime Lies, 200.

55 Binjamin Wilkomirski, Fragments: Memories of a Childhood, 1939-1948 (London: Picador, 1997).

56 Saul Bellow, Mr. Sammler's Planet (New York: Penguin, 1995).

57 Philip Roth, The Ghost Writer (New York: The Library of America, 2007).

58 Cynthia Ozick, The Shawl (New York: Vintage, 1990).
} 
that the trauma may be, at some point, healed. Second-generation accounts are marked by features like parental silence as to their experiences, parental stories of the horrors without hope or contextualization, witnessing the parents' futile attempts to start over again, and the self-imposed role as witness to the results of atrocities as well as to their parents' survival. All of this results in a feeling of helplessness, rage, and near incapability of establishing a stable and independent identity in the face of this legacy.

While the second generation bears the brunt of the ongoing trauma of the Holocaust, it is an indispensable link in working through the collective trauma. As proxy to the trauma, the second generation is overwhelmed by the individual and collective obligations to create a future. In doing so, the second generation is torn in the conflict between its inheritance and its own selves.

Thane Rosenbaum's Second Hand Smoke novelizes such helplessness, rage, and difficulties a child of survivors faces. Trained by his mother to be a Jewish nemesis who pursues all anti-Semites and finally fights back, Duncan Katz grows up as "a child of trauma. Not of love, or happiness, or exceptional wealth. Just trauma. And a nightmare, too." 59 Significantly, his parents' silence about their Holocaust past fills Duncan with fantasies about the events that allow him "to encounter them" imaginatively in the hope to feel at least something, "to be swallowed up [...], to become a prisoner, to actually feel the horror" his parents felt and thereby break the excruciating tension he experiences between their Holocaust suffering and his seemingly comfortable post-Holocaust world. ${ }^{60}$ Duncan is a witness to "the damage that could never be undone. The true legacy of the Shoah. Lives that were supposed to start all over but couldn't. Halting first steps, then the stumbles. The inexhaustible sorrow of the parents; the imminent recognition of the children." 61 For Duncan, children of survivors are "[c]hildren of smoke and skeletons," so that, inadvertently, the "Holocaust shaped those who were survivors of survivors. Inexorably, cruelly, and unfairly so." 62 The development of the narrative is further crafted around the dilemma of survivors who lost children during the Holocaust and had children again. They face the problem of whom to love and whom to care for when their post-Holocaust children are mere surrogates for the lost ones.

Duncan, born after the Holocaust, lacks an identity without the possibility of a memory separate from his parents' trauma. He is indoctrinated by his survivor mother to "avenge our deaths."63 The "ghosts of a robbed childhood" roam this novel of rage, hopelessness, and remembering without the ability to relive the real events. ${ }^{64}$ Yet, he revisits Auschwitz on his trip to Poland, where he wants to find the brother he had never known he had until an uncle reveals Duncan's mother's darkest secret. In Birkenau, accompanied by his Yogi brother, Duncan experiences a terrifying catharsis that enables him to come to terms with the imagined past and gnawing rage.

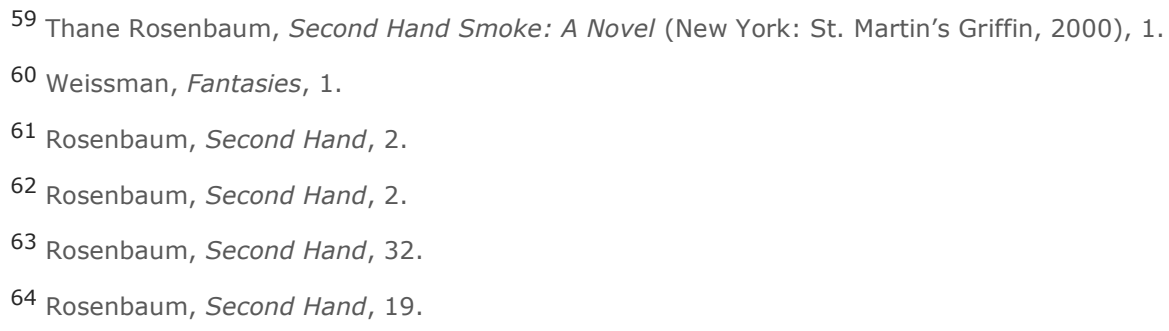


It is this possibility of cathartic moments, by linking first- and second-generation trauma narratives, that constitutes the importance of this generation. Duncan, raised and trained by his traumatized mother "to be alone, to do without," faces his greatest fears in the barracks of Birkenau. He is "paralyzed by the fear of being abandoned. Even my insides know it. My intestines are strangling each other." 65 Duncan, the Nazi hunter, bodybuilder, and martial artist, who fulfills his mother's dreams of an unquenchable flame against anti-Semitic atrocities, is incapable of crushing the fantasies of being selected, incarcerated, and tortured by the Nazis that surface from his (post-)memories. These memories are fantasies born from countless testimonials he read and that constitute the overall collective narrative of the Holocaust from which the post-generations draw their knowledge. Duncan needs his brother, Isaac, who, though born after the Holocaust in a DP camp, is held to be a death-camp survivor by his Polish neighbors and works as a yoga teacher in Warsaw, to make sense of these fears and come to terms with past and present traumata. "Your parents died too soon, and then your wife left you and took your child," Isaac reminds Duncan. "Your stomach is not wrong; you just don't know how to live with the grief."66 Isaac highlights the close connectedness between the past trauma and the present grief. Duncan must separate the two to establish a contemporaneity instead of his state of a past overwriting his present.

Duncan, Isaac points out, should acknowledge that his mother's experiences were of a different nature because she experienced the death camps. Isaac explains to his collapsing brother that he "can't live a normal life with images of the Holocaust playing in [his] head" by showing Duncan the numbers that their mother branded on his forearm: "I am not afraid of them," Isaac says. "You have no numbers, and yet they terrify you. You are hiding from yourself. You are a stranger to yourself. We are locked in this barracks, but you are trapped in yourself even tighter. You buried yourself alive in your own tomb."67 Duncan's problems originate in his struggle to live an identity that is not his but is created by the narratives he forms from his parents' silence and trauma, as well as the seemingly infinite number of Holocaust books cluttering his apartment.

At first, Duncan only realizes that he is

caught in a time warp, trapped in a cattle car. Everything is about loss. It feels like there is no difference between my life and what happened to our family during the war. [...] My life is like one big atonement. Everything is Kaddish. Kristallnacht all over again, but this time the glass is not from broken storefronts, but families. ${ }^{68}$

Duncan emblematizes the second-generation paradigm. He is excruciatingly aware of the difference between then and now, as indicated by his choice of words like "dress rehearsal," "time warp," and "what happened during the war." In fact, it is especially this awareness of a seemingly unbridgeable temporal gap that makes it so unbearable for him. At the same time, he feels the need to pass on the trauma and, in an everlasting process of mourning, violates the very principles of the Kaddish because for him "[t]o mourn is to forget." 69 Duncan

\footnotetext{
65 Rosenbaum, Second Hand, 262.

66 Rosenbaum, Second Hand, 262.

67 Rosenbaum, Second Hand, 262.

68 Rosenbaum, Second Hand, 262-63.

69 Rosenbaum, Second Hand, 264.
} 
transforms the second-generation burden, that is, the inability to feel what his parents' felt during the Holocaust, into his "birthright," which constitutes "a permanent scar."70

To heal this scar, Duncan needs his brother, who symbolizes the connection to the actual trauma and helps Duncan see that he cannot continue to make his parents' past trauma his own contemporaneous identity. Isaac tells Duncan that "rage is all about holding on to something that you don't need but are afraid to let go. You have a life force inside you. It is time to use it for living, and not as a prison. ${ }^{171}$ After living through his own personalbut imagined-Auschwitz nightmare, Duncan is finally able to heed this advice. He establishes his own narrative, in which he incorporates the narrative of his parents' past but which no longer overwrites his own present identity.

\section{Third Generation}

Focusing on continuing the legacy, second-generation literature faces the dilemma that it can only approach the trauma, memory, and history imaginatively. To come to terms with the trauma, second-generation writers incorporate historical (factual) accounts into their fictional narratives. With direct contact with survivors and witnesses quickly becoming less possible, such incorporation and transmission become even more pressing for the third generation. Unlike the children, the survivors' grandchildren have more distance to the actual accounts. However, scholarship suggests that many survivors find it easier to recount their experiences to-or to revisit the Old Country accompanied by-their grandchildren instead of their children. Compared to the third generation's curiosity about their ancestors' past, distance and closeness produce a plethora of new ways of engaging with the trauma. What is more, members of the third generation are more deeply ingrained in the American collective identity and are more likely to engage with the Holocaust in their individual way.

Dara Horn's The World to Come highlights the difficulties the third generation faces: the need to bear witness to memories and traumata of the Holocaust in a world where true witnesses are dying out fast. However, The World to Come emphasizes that such a world to come is not as bleak as it seems. Even in the face of a history full of trauma, pogroms, and atrocities, the past is viewed as an inalienable part of a person's contemporaneity. "I believe," says Ben, the protagonist of The World to Come, "that when people die, they go to the same places as all the people who haven't yet been born. That's why it's called the world to come, because that's where they make the new souls for the future."72 One's predecessors are bound to one's present identity because one is formed by their actions, decisions, choices, and lives. Simultaneously, the past intricately shapes and influences present and future, which is then bound back to a new generation arriving. Past, present, and future are inextricably linked in Horn's narrative conception of the world to come.

The World to Come is filled with these intricate relapses into a past before the Holocaust, a past where trauma already existed in the cloth of narrative. But for Horn, this history full of memory and loss is precisely what constitutes the fascination with it. One character ties "himself up in ropes of memory, caged himself in with iron bars of memory, drew the

\footnotetext{
70 Rosenbaum, Second Hand, 264.

71 Rosenbaum, Second Hand, 264.

72 Dara Horn, The World to Come. A Novel, (New York: Norton 2006), 124.
} 
curtains and hid himself in the dark tomb which he filled with an entire world of memory until all that was missing was color and light." ${ }^{173}$ It is a powerful play on the ambivalence between the actual memory and the belated writing. The characters in The World to Come are torn between preservation (the conservation of knowledge from all previous generations that is taught to the unborn new generations in the world to come) and destruction (the vital forgetting of being born into one's present), liberation (the possibility to start anew), and enslavement (the generational baggage that comes with the past). In that, they mirror the difficulties of a generation that can approach the trauma increasingly only through secondhand narratives. These stories of the past fill one's present because the deceased "give them all the raw material of their souls, like their talents and their brains and their potential."74 There still is hope because "it's up to the new ones, once they're born, what they'll use and what they won't, but that's what everyone who dies is doing, I think. They get to decide what kind of people the new ones might be able to become." 75

In this respect, Horn's work is typical of third-generation writing, as it powerfully shows that the third generation is also characterized by an urge to move on from, instead of merely continue, the trauma. The worlds of the past, present, and future are continuously shifting in and out of $\operatorname{co}(n)$ temporaneity. The world to come becomes the world before: the Yiddish world of Eastern Europe and its plethora of narrative possibilities becomes a foil for the present dreams for the future. Horn and other third-generation writers acknowledge the Holocaust trauma but try to connect to this pre-Holocaust world to create a new life in the post-Holocaust one. The world to come-a future reference in itself-is where present and future merge with the past through predecessorial instruction. In this process, imaginative narratives are paramount because they create meaningful stories that allow for coherence and grounding by filling gaps either fictionally or by incorporating memories of other people.

\section{Future Contemporaneity}

The selected novels deploy a historicization of fiction and a fictionalization of history. Memory and history-as fact, as well as a fictional narrative-are used to produce meaning, to retell the past(s) to create, shape, or meet the present. The novels are bound by their need to bear witness to a traumatic past that entered the fabric of individual and collective identity, although, for the nonwitness generations, it is a past they can never experience themselves. Both first-generation writers such as Begley and second- and third-generation writers like Rosenbaum and Horn constitute a conception of the past as being one possibility among others. Survivors' identities are shaped by the co(n)temporaneity of memories of a trauma that shattered their identities and their past up to the Holocaust. For the following generations, a considerable part of their identity is constituted by the co(n)temporaneity of a past trauma they have not experienced first-hand but, as a collective trauma narrative, overwhelms them nevertheless. If the process of remembering and forgetting is disrupted, both survivors and following generations will suffer a loss of identity-a footing in their present-as the collective trauma narratives take over. The past, in this conception, is a histonarrativistic nexus, that is constituted by individual and collective memories, facts and narratives, toward which the individual feels an urge to connect. While for Wiesel, the

\footnotetext{
73 Horn, World to Come, 200.

74 Horn, World to Come, 124.

75 Horn, World to Come, 124.
} 
Auschwitz self, although shattered metaphorically as an image in a mirror, will always remain a present reality, Duncan Katz, in Second Hand Smoke, needs to develop an identity that is his alone and not a reenactment of other people's memories. In The World to Come, what Alexander calls a progressive narrative, is more palpable again. The $\mathrm{co}(\mathrm{n})$ temporaneous identity consists of the past and moves into a future, which is causally connected to a past of following generations. In this nexus, past, present, and future constitute a conflux of time in the individuals' minds, enabling them to move intellectually backward and forward in time and generationally reshape the collective trauma narratives. Here, trauma can be both cause and effect of disconnection. It might even be the case that reinvention is a new form of trauma. The past is a necessary factor in the establishment of an identity grounded contemporaneously. The lack of a past or its traumatization is a cause for fragmentation. Memory and tradition together form identity in the process of making history $\mathrm{co}(\mathrm{n})$ temporaneous. Likewise, the present can be used to create meaning in the past and shape identity.

The particular version of a collective identity changes with each individual and new generation, as everyone applies his or her personal history and views on collective history to create a new identity. Individual traumata are continuously retold in different narratives to work out and create meaning from various experiences. Collective traumata need to incorporate these stories as well as to meet the audiences' respective imaginative or real contemporaneities. Identity is always in dispute within the novels and their audiences. Identity, as presented and interpreted here, requires constant redefinition and reinterpretation by each individual as well as by entire communities. It must be created from our versions of our pasts-the histories we construct from it-and our present-the meaning we extract from our own worlds. Identity, like history, becomes something the individual creates and chooses. ${ }^{76}$

The characters grapple with their real or invented origins and where they will lead them in the present and future. ${ }^{77}$ The emphasis lies on the essentiality of the past and a meaningful connection to tradition-retelling stories of the past with ever-new meanings, stressing the need to link the past and the present. ${ }^{78}$ The authors and their characters explore the origins of contemporaneous identities. They are united in their attempt to create a meaningful world worth living in, and in their search for meaning and legitimacy in a world that is shaped by the traumata, memories, aspirations, and choices of a nexus of generations of ancestors. ${ }^{79}$ Memory and the past, however, are not just relative or arbitrary stories that can be reinvented according to the individual's pleasure. Certain historical landmarks are necessary, unalterable parts of each story, an underlying individual trauma that cannot and must not be negotiated. Facts like the birth and death of people, or the Shoah, cannot be invented away; one must take them into account while one reinvents one's own personal, meaningful story around or from them.

76 Bryan Cheyette, "On Being a Jewish Critic," in Anglophone Jewish Literature, ed. Axel Stähler (London: Routledge, 2007), 34.

77 Josh Lambert, American Jewish Fiction (Philadelphia: Jewish Publication Society, 2009), 5.

78 Melissa Friedling, "Feminisms and the Jewish Mother Syndrome: Identity, Autobiography, and the Rhetoric of Addiction," Discourse 19 (1996): 109.

79 Jeffrey Rubin-Dorsky, "Philip Roth and American Jewish Identity: The Question of Authenticity," American Literary History 13 (2001): 86. 
The texts represent continued explorations in search of meaning in history and histories they have inherited from their forebears. Moreover, it emblematizes their urge to interpret these meanings in new terms for a new generation. ${ }^{80}$ Nevertheless, the novels emphasize that memory is almost never accurate; it is the meaning and the possibility of creating a whole self in a contemporaneity. Historical truth is only the marginal framework in which the manifold possible realities are narrativized.

These narratives create a special sense of identity and $\operatorname{co}(n)$ temporaneity: not only identity in the sense of identifying oneself with the incidents of history and tradition but also that one's identity is constituted by these incidents as individual stories form collective narratives. ${ }^{81}$ The novels allow this through their conception of "a unique identity which springs from [an] origin and [a] story. ${ }^{\prime 82}$ Each individual has to take this basis of cultural identity to start on their path toward creating and exploring their origins, thereby creating and exploring themselves, thereby creating collective narratives to which others can relate.

(cc) BY New articles in this journal are licensed under a Creative Commons Attribution 4.0 United States License.

\section{ULIS D-Sent}

This journal is operated by the University Library System of the University of Pittsburgh as part of its D-Scribe Digital Publishing Program, and is co-sponsored by the University of Pittsburgh Press.

80 Yosef H. Yerushalmi, Zakhor: Jewish History and Jewish Memory (Seattle: Washington University Press, 1982), 18.

81 Max I. Dimont, The Jews in America: The Roots, History, and Destiny of American Jews (New York: Simon and Schuster, 1978), 216.

82 Ruth R. Wisse, "Jewish American Renaissance," in The Cambridge Companion to Jewish American Literature. ed. Hana Wirth-Nesher and Michael P. Kramer (Cambridge: Cambridge University Press, 2003), 199. 